IMMUNOLOGY CORNER

\title{
Primary Immune Deficiency
}

\author{
Sagar Bhattad \\ Pediatric Infectious Disease (2019): 10.5005/jp-journals-10081-1202
}

\section{Primary Immune Deficiency-Warning SIGNS}

Primary immune deficiencies (PID) are a group of heterogeneous disorders characterized by increased susceptibility to infections, autoimmunity and malignancy due to a defect in the immune system.

\section{What Does the Term "PRimary" Mean?}

Immune deficiencies can be secondary to infections like HIV/AIDS, or drugs like corticosteroids. The term primary in PID means these are "genetic diseases". Any component of immune system-cells, proteins (immunoglobulins), enzymes involved in immune regulation may be at defect causing PID. PIDs are now known as inborn errors of immunity.

\section{Clinical Approach to Immune Deficiency}

A systematic approach is needed to arrive at an appropriate diagnosis in a patient with suspected immune deficiency. One must attempt answering the following questions

(1) Is it an immune deficiency?

Presence of warning signs (described in the Table) would be a strong pointer towards an immune deficiency. Recurrent infections are one of the key manifestations of immune deficiency. One can remember the acronym SPUR-severe, persistent, unusual, recurrent infections. Children and adults presenting with SPUR must be investigated for PID. A vast variety of conditions may cause failure to thrive in an infant and PID is an important consideration in this setting. A detailed family history is of paramount importance in arriving at a timely diagnosis in a child with suspected PID. History of sibling deaths or similar illness in the siblings must make one think of PID.

(2) What is the type of immune defect?

B cell/combined/phagocytic/syndrome.

a. Children with B cell defect (usually have hypogammaglobulinemia) present with repeated bacterial infections affecting respiratory and gastrointestinal tracts. e.g.: pneumonia, otitis media, chronic or recurrent diarrhea. Usual pathogens are S. pneumoniae, H. influenza, S. aureus etc.

b. Presence of opportunistic infections (fungus, virus) must make one think of T cell defect. e.g.: children with severe combined immune deficiency (SCID) may present with persistent oral thrush, cytomegalovirus (CMV) retinitis etc.

c. Children presenting with recurrent suppurative infections empyema, lung abscess, liver abscess and/or suppurative lymphadenitis must be investigated for phagocytic defect (e.g.: chronic granulomatous disease).
Department of Pediatric Immunology and Rheumatology, Aster CMI Hospital, Bengaluru, Karnataka, India; Foundation for Primary Immunodeficiency Diseases (USA) Center, Aster CMI Hospital, Bengaluru, Karnataka, India

Corresponding Author: Sagar Bhattad. Department of Pediatric Immunology and Rheumatology, Aster CMI Hospital, Bengaluru, Karnataka, India; Foundation for Primary Immunodeficiency Diseases (USA) Center, Aster CMI Hospital, Bengaluru, Karnataka, India, Phone: +91 9779433934, e-mail: drsagarbhattad@gmail.com

How to cite this article: Bhattad S. Primary Immune Deficiency. Pediatr Inf Dis 2019;1(2):68-69.

Source of support: Nil

Conflict of interest: None

d. Syndromic appearance with recurrent infections may be seen in DiGeorge syndrome.

(3) What are the organisms?-bacterial/viral/fungal/parasitic. Is it the same group of organisms causing recurrent infections? Or is the spectrum of infections very broad?

a. Children with T cell defects present with broad spectrum of infections-bacterial, viral, fungal, protozoal. e.g.: SCID.

b. Infections with the same group of bacteria (narrow spectrum of infections) point towards a specific PID.

Example: (i) Susceptibility to low virulent mycobacteria (disseminated BCG disease, atypical mycobacterial infections) is noted in Mendelian susceptibility to mycobacterial disease (MSMD).

(ii) Recurrent candidiasis affecting mucosal sites, skin and nails is noted in chronic mucocutaneous candidiasis (CMC).

(4) Family history

As highlighted previously, a detailed family history and evaluation of affected relatives is an integral part of the assessment of a child with suspected PID. Following factors must be kept in mind

a. Presence of consanguinity in parents may point towards autosomal recessive (AR) pattern of inheritance.

b. Only male siblings being affected/maternal uncles being affected-likely X-linked inheritance.

c. Recurrent infections in one of the parents-may point towards autosomal dominant (AD) inheritance. e.g.: AD Hyper lgE Syndrome.

(5) Close look at all the previous hemograms. Calculate absolute neutrophil and lymphocyte counts (ANC and ALC).

a. Absolute neutrophil counts $<1500 / \mathrm{mm}^{3}$ - neutropenia. Neutropenia can be seen in X-linked agammaglobulinemia, hyper IgM syndrome, severe congenital neutropenia.

o The Author(s). 2019 Open Access This article is distributed under the terms of the Creative Commons Attribution 4.0 International License (https://creativecommons. org/licenses/by-nc/4.0/), which permits unrestricted use, distribution, and non-commercial reproduction in any medium, provided you give appropriate credit to the original author(s) and the source, provide a link to the Creative Commons license, and indicate if changes were made. The Creative Commons Public Domain Dedication waiver (http://creativecommons.org/publicdomain/zero/1.0/) applies to the data made available in this article, unless otherwise stated. 
b. Repeated episodes of oral ulcers, infections-look for cyclic neutropenia.

c. In infants, absolute lymphocyte counts $<3000 / \mathrm{mm}^{3}$ is lymphopenia. Persistent lymphopenia in an infant is a strong pointer towards SCID.

(6) Look at the thymic shadow in chest radiograph in infants (if absent, points towards SCID). Absent thymus can be confirmed by ultrasound examination of the neck.

(7) Relevant immunological tests-immunoglobulins, lymphocyte subsets (T, B and NK cell counts), nitroblue tetrazolium test (NBT), dihydrorhodamine dye test (DHR).

a. Recurrent pneumonia/otitis media/diarrhea-look for serum immunoglobulins. Hypogammaglobulinemia + absent $B$ cells in a boy with recurrent infections is diagnostic of X-linked Agammaglobulinemia.

b. Abnormal NBT and DHR tests suggest a diagnosis of Chronic granulomatous disease.

(8) Genetic testing

Genetic testing is essential for confirmation of the diagnosis in a child with suspected PID. However, one must remember, this is not a prerequisite to initiate treatment. Children diagnosed to have hypogammaglobulinemia with a relevant clinical background must be started on immunoglobulin infusions, and such treatment must not be delayed for the want of genetic confirmation. Genetic testing can be carried out by next generation sequencing (NGS), and results can later be confirmed by Sanger sequencing. However, ordering NGS test in the absence of appropriate clinical background and immunological screening tests would often fail to provide meaningful results. Genetic confirmation of PID is essential for genetic counseling of the affected families and this provides scope for antenatal testing and prevention of these diseases.

(9) Functional studies if indicated

A small subset of children with normal immunoglobulin levels may fail to mount response to certain pathogens, e.g.: specific antibody deficiency. Thus, a complete immunological evaluation must incorporate functional studies.

a. Postvaccination titers: low titer is a pointer towards humoral immune deficiency, e.g. common variable immune deficiency.

b. T-cell proliferation assays: defective T-cell proliferation is characteristic of a T cell defect, e.g. SCID.

Functional studies are currently available only in selected laboratories (research laboratories) and hence translation of these tests for patient care has been a challenge so far.

\section{Warning Signs of Primary Immune Deficiency}

Awareness regarding PID improves timely diagnosis and health service delivery to affected patients; hence warning signs of PID should be kept in mind. The hallmark of PID is recurrent infections. When infections with atypical severity, atypical pathogens, or frequency higher than expected are observed, physicians should investigate for possible immune deficiency. Popularly used warning signs of PID that have been valuable in raising awareness are listed in Table 1.

Table 1: Warning signs in children and adults

\begin{tabular}{|c|c|c|}
\hline Number & Warning signs in children & Warning signs in adults \\
\hline 1 & $\begin{array}{l}\text { Recurrent ear, nose, or } \\
\text { throat infections; four or } \\
\text { more new infections within } \\
1 \text { year }\end{array}$ & $\begin{array}{l}\text { Recurrent ear, nose, or } \\
\text { throat infections; two or } \\
\text { more new infections within } \\
1 \text { year }\end{array}$ \\
\hline 2 & $\begin{array}{l}\text { Two or more serious sinus } \\
\text { infections within } 1 \text { year }\end{array}$ & $\begin{array}{l}\text { Two or more serious sinus } \\
\text { infections within } 1 \text { year }\end{array}$ \\
\hline 3 & $\begin{array}{l}\text { Two or more pneumonias } \\
\text { within } 1 \text { year }\end{array}$ & $\begin{array}{l}\text { One pneumonia per year } \\
\text { for more than } 1 \text { year }\end{array}$ \\
\hline 4 & $\begin{array}{l}\text { Two or more months } \\
\text { on antibiotics with no } \\
\text { improvement or little effect }\end{array}$ & $\begin{array}{l}\text { Recurrent viral infections } \\
\text { (colds, herpes, warts, } \\
\text { condyloma) }\end{array}$ \\
\hline 5 & $\begin{array}{l}\text { Two or more deep-seated } \\
\text { infections including } \\
\text { septicemia }\end{array}$ & $\begin{array}{l}\text { Infection with normally } \\
\text { harmless tuberculosis-like } \\
\text { bacteria }\end{array}$ \\
\hline 6 & $\begin{array}{l}\text { Failure to thrive from early } \\
\text { infancy }\end{array}$ & $\begin{array}{l}\text { Chronic diarrhea with } \\
\text { weight loss }\end{array}$ \\
\hline 7 & $\begin{array}{l}\text { Infection with atypical } \\
\text { severity; recurrent pyogenic } \\
\text { infections such as deep skin } \\
\text { or organ abscesses }\end{array}$ & $\begin{array}{l}\text { Infection with atypical } \\
\text { severity; recurrent, deep } \\
\text { abscesses of the skin or } \\
\text { internal organs }\end{array}$ \\
\hline 8 & $\begin{array}{l}\text { Infection with atypical } \\
\text { pathogens; persistent } \\
\text { thrush in mouth or fungal } \\
\text { infections on skin }\end{array}$ & $\begin{array}{l}\text { Infection with atypical } \\
\text { pathogens; persistent } \\
\text { thrush in mouth or fungal } \\
\text { infections on skin }\end{array}$ \\
\hline 9 & $\begin{array}{l}\text { Need for intravenous } \\
\text { antibiotics to clear } \\
\text { infections }\end{array}$ & $\begin{array}{l}\text { Recurrent need for } \\
\text { intravenous antibiotics to } \\
\text { clear infections }\end{array}$ \\
\hline 10 & Family history of PID & Family history of PID \\
\hline
\end{tabular}

Presence of two or more warning signs warrants an evaluation for an underlying PID 